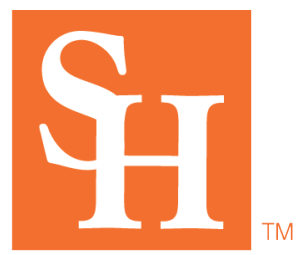

Sam Houston State University

Department of Economics and International Business

Working Paper No. 16-06

May 2016

\title{
THE BALLOT ORDER EFFECT IS HUGE: EVIDENCE FROM TEXAS
}

\author{
Darren Grant* \\ Department of Economics and International Business \\ Sam Houston State University \\ Huntsville, TX 77341 \\ dgrant@shsu.edu
}

\begin{abstract}
* This project was inspired by my friend J. T. Langley, who ran a little too hard in a contest his opponent had dropped out of, and funded by a Sam Houston State University Faculty Research Grant and an SHSU College of Business Administration Summer Research Grant. The dedicated assistance of Evan Arambula, Anusha Dasari, Daniel Jones, Ahmet Kurbanov, and Jared Zbranek is greatly appreciated, along with that of the many dedicated election administrators throughout the State of Texas, for their considerable efforts locating and sending to us the ballot order information needed for this research. Helpful comments by Kosuke Imai, Jon Krosnick, Thomas Stratmann, and participants at the 2016 Public Choice Society meetings are also greatly appreciated.
\end{abstract}




\begin{abstract}
Texas primary and runoff elections provide an ideal test of the ballot order hypothesis, because ballot order is randomized within each county and there are many counties and contests to analyze. Doing so for all statewide offices contested in the 2014 Democratic and Republican primaries and runoffs yields precise estimates of the ballot order effect across twenty-four different contests. Except for a few high-profile, high-information races, the ballot order effect is large, especially in down-ballot races and judicial positions. In these, going from last to first on the ballot raises a candidate's vote share by nearly ten percentage points.
\end{abstract}

Keywords: Voting; Ballot order; Behavioral economics

JEL Codes: D72 
The phenomenon known as the "ballot order effect" implies that candidates who are listed earlier on the ballot will receive a greater share of the vote, all else equal. This effect, if sizable, could influence the democratic process by delivering elections to those candidates who were fortunate enough to be listed first, instead of the candidates actively preferred by the most voters. Accordingly, some states carefully establish the procedures for determining ballot order. Lawsuits have resulted from elections that did not follow these procedures (Alvarez, Sinclair, and Hasen, 2006).

Several scholars have attempted to estimate the size of the ballot order effect. Early efforts had significant methodological problems (Darcy and McAllister, 1990; Miller and Krosnick, 1998; Ho and Imai, 2008), which have been largely corrected in more recent studies. Fourteen of these have been published in the last twenty years, ten of which focus on the U.S. ${ }^{1}$ These studies are, however, quite concentrated in their geography, election type, and office contested.

This is shown in Table 1, which summarizes these studies' characteristics and findings. Half focus on California (Alvarez, Sinclair, and Hasen, 2006; Ho and Imai, 2006, 2008; Meredith and Salant, 2013; Pasek et al., 2014), and eight of the ten on California, Ohio, and/or North Dakota (Miller and Krosnick, 1998; Krosnick, Miller, and Tichy, 2004; Chen et al., 2014). Similarly, half of these studies focus on general elections (Alvarez, Sinclair, and Hasen, 2006; Krosnick, Miller, and Tichy, 2004; Miller and Krosnick, 1998; Chen et al., 2014; Pasek et al., 2014), with just two studies of primaries (Koppell and Steen, 2004; Ho and Imai, 2008) and none of runoffs. Furthermore, while contests for federal and state executive positions are well-represented, only one study includes state

${ }^{1}$ These ten are all cited in the subsequent paragraph, except for Brockington (2003), a study of local elections in Peoria, Illinois. The four studies examining elections abroad are Fass and Schoen (2006), for Germany; King and Leigh (2009), for Australia; Lutz (2010), for Switzerland; and Marcinkiewicz (2014), for Poland. There is also a small U.S. literature on the effects of ballot order on the passing rates of propositions and bond issues. See Matsusaka (2016) for a review and recent evidence from propositions in California and Texas. 
legislative positions (Koppell and Steen, 2004) and only two include state judicial positions (Miller and Krosnick, 1998; Chen et al., 2014).

Given this concentration, a simple average of these studies' findings could obscure many truths about the ballot order effect. This average would conclude that ballot order effects are statistically significant but fairly small: moving from last to first on the ballot would increase a candidate's vote share by less than three percentage points. This may be true for general elections, which dominate the recent literature, but elsewhere this need not always be true, as the table suggests. These alternatives are somewhat sparsely studied, however. Given the importance of replication in science and the potential sensitivity of the ballot order effect to geographic area, election type, or contest studied, further study of the ballot order effect is needed (as stressed by Chen et al., 2014).

The state of Texas is an ideal location for such a study. In 2014, it held contested primary and runoff elections in both major political parties for federal legislative positions, a variety of state executive positions, and several judicial positions. It is located in the South, a region unstudied to date. And, in each election, state law requires ballot order to be randomized at the county level, across each of Texas's 254 counties. This randomization, which figuratively (and, in places, literally) amounts to drawing ballot order out of a hat, is unique to the U.S. literature and approximates the ideal "natural experiment" one would wish to have in order to investigate this phenomenon, maximizing the analysis' statistical power and facilitating a examination of the influence of demographic and economic factors on the magnitude of the ballot order effect.

Our findings are striking. We first discover evidence of ballot order manipulation in a small number of high-profile races: the distribution of some candidates' ballot positions deviates notably from that expected by chance. Furthermore, while the ballot order effect is small in high-profile races 
for U.S. Senator, Governor, and Lt. Governor, it is larger elsewhere; in down-ballot judicial elections it equals or exceeds ten percentage points, the largest estimated effect in the modern U.S. literature. These effects vary little with demographic and economic factors. In down-ballot primary and runoff elections in Texas, the ballot order effect is huge.

\section{Section 1. Background.}

Texas holds general elections for offices elected on a partisan basis in November of evennumbered years. In these elections ballot order is based on each party's votes in the previous gubernatorial election, and thus is not randomized. Party primaries, held the previous March, and primary runoffs, held in May, are another matter. Texas Elections Code 172.082 requires that:

(a) The order of the candidates' names on the general primary election ballot for each county shall be determined by a drawing.

(b) The county executive committee shall conduct the drawing unless it provides by resolution that the drawing be conducted by the primary committee.

(c) The drawing shall be conducted at the county seat not later than the 10th day after the date of the regular filing deadline for the general primary election.

(d) Each candidate affected by a drawing is entitled to be present or have a representative present at the drawing.

(e) The county chair shall post notice of the date, hour, and place of the drawing for at least 24 consecutive hours immediately before the drawing begins. The notice shall be posted on the bulletin board used for posting notice of meetings of the commissioners court. If the party maintains an Internet website, the party shall post the notice on the party's website. All candidates who provide an e-mail address on their filing form shall be notified electronically.

If one could design a field experiment to gauge the size of the ballot order effect, it would replicate this procedure: conduct elections with the same candidates in multiple jurisdictions, choosing 
their ballot order at random in each one. Surprisingly, this "experiment" appears to be unique in the literature. Three of the states studied previously, Ohio, New York, and North Dakota, use a precinctlevel rotation system, moving the first name to last in each successive precinct. California uses a rotation system for state offices, rotating the order among its eighty assembly districts, and a single order for local elections. Though the rotation system engenders some empirical complications (see Alvarez, Sinclair, and Hasen, 2006; Ho and Imai, 2008, and Pasek et al., 2014, for further detail), it is legitimate for analysis. The primary empirical advantages of county-level randomization is that it removes these empirical complications and allows county-level demographic and economic variables to be included in the analysis, both as controls and as moderators of the ballot-order effect. In addition, the randomization itself is of interest, as we shall see.

Figure 1 depicts the first page of the Republican sample ballot for one Texas county, Hardin County, for the March 2014 primary. Federal races, for the U.S. Congress, are listed first, followed by state offices elected statewide, such as Governor. These are followed by state offices elected regionally, such as State Representative, District Court Judge, or Appeals Court Justice, which, in turn, are followed by county offices including District Judge (the chief county official, and not a judge in the traditional sense) or County Clerk, followed by a subset of precinct-level offices such as County Commissioner, Constable, or Justice of the Peace (many counties have four of each). Non-partisan elections for city councilmen, school trustees, board members of hospital districts, etc., are held on a different date in May, or in November, and thus do not appear on primary or runoff ballots. Note that incumbents are not identified on the ballot. Among state executive positions, however, only one incumbent ran for re-election (Republican Lt. Governor David Dewhurst, who lost in the runoff).

Our analysis includes only those state offices elected statewide, along with the one federal 
office selected statewide in 2014, U.S. Senator. These state offices include high-profile contests for the two most powerful executive positions in Texas government, Governor and Lt. Governor (traditionally considered more powerful than the Governor), which attract great attention and wellknown, well-funded candidates. Other positions include other executive offices such as Land Commissioner or Comptroller, a seat on the Railroad Commission (which regulates the oil and gas industry), and several places on each of Texas's two highest courts, the Supreme Court (for civil cases) and the Court of Criminal Appeals (for criminal cases). This amounts to a total of twenty-four different contests for fourteen different positions, involving a total of fifty-nine candidates.

It is worth nothing that Hardin County, with 55,000 people, is three times as populous as the median Texas county. Even using the weighting scheme described below, the median is barely over 25,000 . Sparsely populated counties dominate our sample. It is important to recognize that in these counties many voters will personally know, and may be related to, one or more of the candidates for local office. Many county offices, such as those listed above, are considered "good jobs" for that area, and candidates for these positions will often campaign extensively, door to door, farm to farm, or ranch to ranch, in order to be elected to them. (California, in contrast, has far fewer county offices on the primary ballot yet far more populous counties, differences that could substantially affect the social dynamics of primary elections.) In Texas, it is reasonable to expect some fraction of primary and runoff voters to be relatively unconcerned with, and uninformed about, statewide contests, especially those down-ballot. (The same holds true for runoffs, though to a lesser extent, as many local contests are fully resolved in the primary.)

Formal evidence on this point, though limited, supports this claim. Campaign spending in 2014 can be obtained from the Texas Ethics Commission, the Texas Tribune, and various newspaper 
articles. Major candidates for Governor and Lt. Governor, in both parties, spent around $\$ 5$ million on the primary. In races further down-ballot, such as Agriculture Commissioner, top-tier candidates' primary spending ranged from $\$ 1-5$ million, which is not large given Texas' size and population. Campaign spending in judicial elections, in contrast, was very low. In the primaries for the Court of Criminal Appeals, for example, total spending-not for one candidate or one race, but by all seven candidates for all three contested seats combined-failed to top $\$ 200,000$. In general, the cost per vote in the 2014 primaries was around $\$ 10$ for up-ballot races, closer to $\$ 5$ for other statewide, nonjudicial races, and pennies for judicial elections. As most of this spending goes to advertising, which communicates information about the candidates to voters, we can expect voters to know more about the candidates in up-ballot elections.

Polling evidence, though similarly limited, also supports this claim. The only primary poll available, conducted by the Texas Tribune in early February, 2014, asked about several statewide races, and recorded the fraction of respondents without a strong candidate preference ("which of the following candidates would you vote for, or haven't you thought about it enough to have an opinion?"). In the Republican primaries for U.S. Senator, Governor, and Lt. Governor, around 30\% of voters had no strong preference; in those for Attorney General and Comptroller, the percentages were around $50 \%$. Voters' preferences over candidates were more formed for the high-profile, upballot races. Unfortunately, as the poll only queried about a limited number of races, a similar comparison cannot be made on the Democratic side or with judicial contests.

Finally, the vote itself suggests that voters' preferences are more formed for up-ballot contests: as one moves to contests further down-ballot, more voters abstain from registering a preference. The Republican primaries for Governor and Lt. Governor each had about 1.34 million 
total votes. The next five races, ranging from Attorney General to Railroad Commissioner, averaged 1.23 million. The contested Supreme Court and Court of Criminal Appeals races that followed them averaged only 1.13 million. This sizeable rate of abstention probably stems, more than anything, from poor knowledge of the candidates in those races.

\section{Section 2. Data.}

To learn the ballot order of each race in each county, we requested copies of each Texas county's sample ballot for each (Democratic and Republican) primary and runoff election held in March and May 2014, respectively. County election officials are obligated under Texas' Freedom of Information Act to provide these copies. After an extensive effort, we obtained responses from all counties, but received only a subset of ballots from a few. ${ }^{2}$ As Table 2 shows, in total we received $99 \%$ of all primary ballots and $97 \%$ of all runoff ballots, accounting for well over $99 \%$ of all votes cast. In Texas, primaries and runoffs are supervised by the county chair of each party in each county. If there is no party chair, or the party chair decides not to have an election, no election is held. This happens in several counties, for each party. Thus, in total, the number of sample ballots obtained ranges from 222, in the Democratic Runoff, to 245, in the Republican Primary.

To this data we appended the county-level results of each of these elections, available from

${ }^{2}$ The effort spanned ten months and utilized hundreds of man-hours. While most counties were prompt and professional in responding to these requests, a non-trivial number required repeated callbacks in order to obtain the requested information. Skilled labor supply can be scarce in Texas's many sparsely-populated counties, and it was not unusual for requests to be overlooked or disregarded, records to be lost or misplaced, the wrong sample ballots sent, or even the existence of a runoff election in that county to be denied. 
Texas's Secretary of State, and various county-level control variables that might influence candidates' vote shares, obtained from the U.S. Census, the U.S. Department of Agriculture, the Texas Secretary of State, and the Texas Association of Counties. Demographic controls include the fractions of the population that are Anglo, black, and Hispanic; the percentage of adults with at least a high school diploma and with a college degree; the percentage of housing that is owner-occupied; and median age. Variables related to the health and structure of the economy include per capita income, the unemployment rate, mean annual rainfall, and the $\log$ of the value of agricultural production. Also included are the logarithms of population, area, the number of registered voters, the number of voters in that election, and the number of votes received by that party's 2012 Presidential nominee (John McCain or Barack Obama). By measuring each in logs, these five variables implicitly also control for population density, voter turnout, and the number of "crossover" voters in each election. ${ }^{3}$ The most recent available measure of each is used, as of 2015; the vintages range from 2010 (for owneroccupied housing) to 2014 (for unemployment). Table 3 gives these variables' descriptive statistics.

How precisely can the ballot order effect be estimated given this data? An approximation can be calculated for the simplest case, in which there are just two equally popular candidates and no control variables. Using the fact that each candidate will be listed first on half the ballots, on average, and the observed standard deviation of candidates' vote shares in the data, one can calculate the expected standard error of the slope coefficient in the univariate regression of vote share on ballot

${ }^{3}$ Texas voters do not register by party. Thus, in Republican-dominated counties, it is not that unusual for Democratic-leaning voters to vote in the Republican primary, and vice-versa for Democratic-dominated counties. 
order under the null. ${ }^{4}$ It equals 0.8 percentage points, which means that in each two candidate election, ballot order effects less than two percentage points can be resolved with statistical significance. The standard errors will be lower for multi-candidate elections, when controls predict vote shares well, and when vote shares are more uniform across counties.

This increased precision, relative to some earlier studies of the ballot order effect, stems from a combination of two factors: a large number of jurisdictions (counties) in which each election is held, and the fact that Texas randomizes ballot order across jurisdictions holding the same election. In consequence, we can discern meaningful differences in the ballot order effect across different types of elections: primaries vs. runoffs, executive vs. judicial positions, Democrat vs. Republican, highprofile "up-ballot" contests, such as those for U.S. Senator, Governor, and Lieutenant Governor vs. low-profile, "down-ballot" contests such as those for judicial positions. Similarly, we can also estimate how the magnitude of the ballot order effect relates to county characteristics, as discussed below.

\section{Section 3. Methods.}

Because ballot order is randomly determined, the most natural approach for analyzing the data

${ }^{4}$ With no controls and two candidates, the matrix of independent variables, $\mathrm{Z}$, in the regression specified below has ones in the first column and the variable FIRST in the second column. The variance of OLS coefficients is $\sigma_{\varepsilon}^{2}\left(\mathrm{Z}^{\mathrm{T}} \mathrm{Z}\right)^{-1}$, where $\sigma_{\varepsilon}^{2}$ is the variance of the error term. If there is no ballot order effect, then $\sigma_{\varepsilon}^{2}$ equals the variance of either candidate's vote share, $\sigma^{2}{ }_{s}$. Thus, given $\mathrm{N}$ counties with ballot order determined randomly in each county, in the limit $\mathrm{Z}^{\mathrm{T}} \mathrm{Z}$ equals a diagonal matrix with $\mathrm{N}$ as the first element on the diagonal and $\mathrm{N} / 2$ as the second element. Using these facts is it straightforward to calculate that the standard deviation of the estimate of the slope coefficient is approximately $\left[2 \sigma^{2} / \mathrm{N}\right]^{\wedge 1} / 2$. In the data $\sigma_{\mathrm{s}} \approx$ nine percentage points, and $\mathrm{N}=254$ counties, so the above expression equals about 0.8 percentage points. 
would appear to be analysis of variance, with ballot order being the "treatment." However, because vote shares are proportions, the assumptions for an analysis of variance are not met (Jaeger, 2008). The preferred alternative is regression, which also allows control variables that can influence candidates' vote shares to be included in the analysis.

This approach is most easily illustrated for a runoff election between two candidates, Adams and Jones, with the candidate who is listed first on the ballot determined at random in each county. The regression posits that the vote share received by Adams, A, is related to ballot order and control variables $\mathrm{X}$ as follows:

$$
A_{c}=\alpha+\beta F I R S T_{c}+\delta X_{c}+\varepsilon_{c}
$$

where FIRST equals 1 if Adams is listed first on the ballot and zero otherwise, $\varepsilon$ is an error term, and $\alpha, \beta$, and $\delta$ are coefficients. The subscript $\mathrm{c}$ indexes counties. The ballot order effect implies $\beta>0$, which is the alternative to the null hypothesis of $\beta=0$.

For an election with multiple candidates, a set of $\beta$ coefficients, $\beta_{1}, \beta_{2}$, etc., capture the effect of each ballot position on the vote share relative to the omitted category, which is being listed last. A separate regression is estimated for each candidate but one; we adopt the convention of omitting the candidate who received the fewest votes. Thus, for an election with $\mathrm{T}$ candidates, the system to be estimated is as follows:

$$
S_{i, c}=\alpha_{i}+\sum_{p=1}^{T-1} \omega_{p} B_{i, c}^{p}+\delta_{t} X_{c}+\varepsilon_{i} \quad \text { for } i=1 \ldots T-1
$$

where $\mathrm{c}$ indexes counties, as before, i indexes candidates, $\mathrm{p}$ indexes ballot position (first, second, third, etc.), $\mathrm{S}_{\mathrm{i}, \mathrm{c}}$ is the vote share of candidate $\mathrm{i}$ in county $\mathrm{c}$, and $\mathrm{B}_{\mathrm{i}, \mathrm{c}}^{\mathrm{p}}$ is a dummy variable that equals 
one if candidate $\mathrm{i}$ is listed in the $\mathrm{p}^{\text {th }}$ position on county c's ballot and zero otherwise. The vectors $\alpha$, $\omega$, and $\delta$ contain regression coefficients. The null hypothesis of no ballot order effect implies that the vector $\omega$ equals zero.

This system is estimated with seemingly unrelated regression, to account for those intercandidate correlations in popularity that are not captured by our controls (see Alvarez, Sinclair, and Hasen, 2006). The counties are not, and should not be, weighted equally. Following the turnout literature (for example, Grant, 1998), candidates' vote shares vary across counties not only because of differences in their popularity, but also because of "sampling error," that is, variation in which voters decide to go to the polls. Furthermore, this sampling error differs even among candidates in the same contest in the same county. ${ }^{5}$ While this latter source of variation is minor in jurisdictions with even one hundred voters, 220 of the elections in our sample have fewer than one hundred voters, and 33 have fewer than ten. Fortunately, simulations discussed in Appendix A, below, indicate that a simple formula gives nearly optimal weights. This formula, in which the weight equals one half the base-10 logarithm of the number of voters, is utilized in our estimations.

Also, this system estimates a single parameter for the effect of each ballot position on vote share, and does not try to estimate separate $\omega$ parameters for individual candidates. In a two candidate election, this would be pointless: the estimate of $\beta$ would be identical if the regression were specified in terms of Jones' ballot position and vote share instead of Adams'. But a similar equivalence principle holds for multi-candidate elections as well. Elections are zero sum: the sum of candidates' vote shares must equal one. Randomly interchanging the ballot order of any two

${ }^{5}$ If each eligible voter has an equal chance of appearing at the polls, then the distribution of votes for any candidate will be binomial. The variance of this distribution, and thus the sampling error in that candidate's vote share, depends on that candidate's popularity. 
candidates' ballot positions cannot increase the sum of candidates' vote shares. Appendix B shows that this implies that the ballot order effect should be equivalent across all candidates in that election. This can be tested by estimating a slight generalization of equation (2), which allows separate $\omega$ coefficients for each candidate, and treating the hypothesis that these effects are equivalent across candidates as the null. This restriction was rarely rejected ( $2 \%$ of the time at the $5 \%$ level), so we simply impose it at the outset.

\section{Section 4. Results.}

$\underline{\text { Randomization. }}$ Table 4 presents evidence on the degree to which ballot order is, in fact, random. Two candidate races are listed in Table 4a, with selected results for multi-candidate races following in Table $4 \mathrm{~b}$. With important exceptions, to be discussed momentarily, ballot order generally appears to be randomized. In two candidate races, for example, the more fortunate candidate is listed first on the ballot about $52 \%$ of the time, which is well within two standard errors of $50 \%$. In multicandidate races, similarly, the fraction of ballots on which each candidate is listed first typically approaches the reciprocal of the number of candidates. This should not be surprising, as there was an informal enforcement mechanism: the presence of candidates at the drawing of ballot order, which is reasonably common, and which increases the chances that this drawing is conducted in accordance with state law.

With dozens of candidates and races, one must cast a jaundiced eye on small p-values: some null hypotheses will probably be rejected due to random chance. Nonetheless, there are clear exceptions to randomization, and these exceptions follow a clear rule: popular candidates in up-ballot 
races are more frequently listed first. The most striking example of this occurs in the Democratic Runoff for Senate, in which party favorite David Alameel is listed first on $73 \%$ of the ballots, vs. $27 \%$ for his opponent, Kesha Rogers, a supporter of Lyndon LaRouche who compared President Obama to Hitler and called for his impeachment. To a much smaller degree, evidence of ballot order manipulation is observed in the Democratic Senate primary and the Republican Primaries for Governor and Lt. Governor, as well as in two down-ballot races.

For multi-candidate races, a test of the joint hypothesis of ballot order randomization across all candidates in the same contest should also be presented. Standard tests for the equality of proportions do not apply, however, because the distributions of ballot order across candidates in the same contest are not independent, and the overall proportions of ballot order are known. The correct test, which takes these facts into account, is the Fisher exact test, which calculates the probability of the given distribution of ballot orders across all candidates in a given contest and rejects the null hypothesis of randomness for distributions that are sufficiently improbable. For races with more than three candidates, however, this test is computationally intensive and would rarely execute. ${ }^{6}$ Table $4 \mathrm{~b}$ presents the results, when available. With one exception the null of random ballot order determination could not be rejected.

Each table also presents the p-values from likelihood ratio tests that relate ballot order to the control variables that are utilized in our vote share regressions below. The p-values are almost uniformly distributed on the unit interval, giving little evidence that ballot order manipulation is related to the predictable component of candidate popularity. Thus, while ballot order randomization

${ }^{6}$ The memory requirements are very large. The author has derived a second-best workaround that is easily implemented in all circumstances. This is available as an Excel spreadsheet upon request; however, the method, and the results obtained using it, are not presented here. 
does not always pertain, it need not bias the coefficient estimates, as long as the failure to randomize is itself not systematically related to candidate popularity.

With these findings in hand, we first conduct our basic estimations, then examine the extent of bias, and then explore how the ballot order effect relates to demographic and economic variables.

Basic Results. Table 5 presents our main findings. The table is organized by election: the Democratic and Republican primaries come first, followed by their respective runoffs. The ballot order effect is estimated relative to being listed last on the ballot, which is indicated by a zero. When a row does not contain a zero, as for the Democratic primary for U.S. Senator, there are five candidates (except for the Republican senatorial primary, which has eight, as indicated in the table). Because the standard errors are virtually identical for each coefficient estimate within a given election-yet another consequence of randomization-the median standard error on these estimates is given in the last column of the table. While these standard errors vary with the closeness of the contest, the evenness of ballot position across candidates, and the variation in candidate popularity across counties, they rarely exceed one percentage point, as approximated above.

Most cells of the table contain three coefficient estimates, which come from regressions that contain increasing numbers of controls. The middle estimate, without parentheses or brackets, utilizes the model laid out above, and is our focus in this subsection. While it would be typical to begin with unconditional means, these will be used as an indirect check for bias, and hence will be discussed, along with the other estimates, in the next subsection. The coefficient estimates on the control variables, which differ for each candidate in each election, are not listed. Collectively, they typically explain one-quarter to one-third of the variance in candidates' vote shares. 
We first discuss the estimates for "first position": that is, being listed first on the ballot instead of last. Across all twenty-four contests, the effect is invariably positive and, with two exceptions in runoff elections, statistically significant. The smallest effects are found in high-profile, highinformation races: the Republican primary for U.S. Senator, which featured the incumbent, John Cornyn; the governor's race, which featured long-time Attorney General Greg Abbott; and Land Commissioner, which featured well-known political newcomer George P. Bush. In these races the ballot order effect is only one or two percentage points.

Larger estimates obtain for most "medium-profile, medium-information" races such as Comptroller, Railroad Commissioner, or the Democratic nominee for U.S. Senator. Most of these fall in a fairly tight band that ranges from three to five percentage points. Estimates are even larger in the low-profile, low-information judicial elections, generally ranging from seven to ten percentage points. Overall, the ballot order effect tends to be larger in contests that receive less attention and in which voters are likely to know less about the candidates on the ballot.

We now turn to the other positions on the ballot, which pertain in races with more than two candidates. In these estimates two regularities appear. First, the effect declines monotonically in ballot order, with second position being less beneficial than first position, third less beneficial than second, and so on. Second, the change also declines monotonically: the difference in the ballot order effect between first and second position is larger than that between second and third position, and so on. Beyond third position the ballot order effect is always small, often insignificant, and occasionally slightly negative.

Overall, the ballot order effect is consistently observed across these twenty-four races. Within each race, as one moves higher on the ballot, one's vote share increases at an increasing rate; the 
largest effect always occurs at first position. The effect sizes range from as little as one percentage point to as much as ten, with larger effects found further down-ballot.

Bias. Because the deviations of ballot order from random are fairly small, except for the Alameel/Rogers runoff, bias will only be substantial if these deviations are closely related to the error term. Two of the largest deviations are in the Democratic Gubernatorial Primary and the Republican Primary for Chief Justice of the Supreme Court, two-candidate races in which the eventual winner was listed first on roughly $56 \%$ of the ballots. We imputed the resulting bias assuming that fully $6 \%$ of counties reversed ballot order to favor these candidates, and that the error term in these counties equaled the median positive residual among those counties that listed these candidates first on the ballot. Under these strong assumptions, the resulting bias was only two percentage points.

In practice, however, the bias appears to be much smaller than this. We gauge its extent by both adding and subtracting controls from our basic regression specification. The first approach is to simply remove all controls from the specification above, which is equivalent to calculating the weighted means of candidates' vote shares by ballot position, and then taking their difference. To the extent that ballot order determination is related to candidate popularity, this uncontrolled estimate should be notably larger than the estimate with controls, because these controls typically explain onequarter to one-third of the variance in candidate popularity.

This almost never happens, however. The estimates are found in the top number in each cell of Table 5 , in parentheses. The coefficient differences are almost always quite small, and are negative as often as they are positive. Only two deviations exceed one percentage point. These occur in two up-ballot Democratic races: the highly non-randomized Senate Runoff mentioned earlier, along with 
the gubernatorial Primary, in which the uncontrolled estimate is nearly four percentage points higher than the controlled estimate. This suggests that, were there further measurable predictors of candidate popularity, the estimated ballot order effect in these races would be diminished yet further. The others would remain more or less the same.

Thus, if there is systematic bias due to ballot order manipulation, it must be unrelated to observable predictors of vote share. We can investigate this using the ballot order in other races-specifically, races in which ballot order has been manipulated across the state. As Appendix B shows, controlling for ballot order in these races can, under somewhat simplified but reasonable assumptions, remove not just some but all bias in the estimates. We thus incorporate the most unbalanced Democratic ballot order, that of eventual nominee David Alameel for in the runoff for Senate, as a control in all other Democratic races. Similarly, we incorporate the two most unbalanced Republican ballot orders as controls in the Republican races: dummies for whether Greg Abbott and Dan Patrick, both eventually elected as Governor and Lt. Governor, were listed first on the primary ballot. Our estimates suggest that about 2/3 of the counties listing Alameel first did so deliberately, as did nearly $1 / 4$ of the counties listing Abbott and Patrick first.

The coefficient estimates are found in the bottom number in each cell of Table 5 , in brackets. Upon inclusion of these controls, the estimates change very little from those above them. Thus, with few exceptions, both bias checks indicate that most estimates are little affected by bias. In Texas, the ballot order effect is real, and in down-ballot judicial elections, it is huge.

Influences on the Ballot Order Effect. Two potential influences on the size of the ballot order effect can be gauged using the results in Table 5: party and election type. Comparing Democratic and 
Republican races suggests a larger effect in the former, as found by Ho and Imai (2008), but the number of races available to compare is small. Comparing runoffs to primaries, the effects appear to be smaller in runoffs, which feature fewer, better-informed voters. But the difference is not large.

We can examine more formally whether the ballot order effect is sensitive to demographic or economic variables. To do so, we focus on the fourteen two-candidate races, and conduct regressions that append, to our original specification, interactions of the "first on ballot" dummy with the following county-level variables: the percentage of the population that is Anglo, per capita income, the percentage of households that own their own home, the percentage of adults that have graduated from high school and from college, and the logarithms of population and area. As in equation (1), the estimates do not depend on which candidate is considered the reference point.

Table 6 presents the coefficient estimates. As might be expected, these are quite variable across the fourteen contests. Thus, at the bottom of the table, we have calculated the median estimate for each interaction term, and used this median to calculate the influence of a one standard change in the independent variable on the ballot order effect.

These calculations indicate that the magnitude of the ballot order effect is not meaningfully influenced by any of these controls. None take the same sign in at least two-thirds of the fourteen contests, and only one is significant with the same sign in at least one-third of the contests. This variable, the percentage of households owning their own home, also has the largest the influence on the ballot order effect. But this influence is modest: a one standard deviation increase in this variable decreases the ballot order effect by just over one percentage point. As homeowners have a greater financial stake in the quality of governance and are more likely to turn out to vote (Grant, 1998), this finding supports an information interpretation of the ballot order effect. Still, it remains accurate to 
say that people are more alike than different in the way that ballot order influences vote share.

\section{Section 5. Discussion and Conclusion.}

A large literature in behavioral economics indicates that individuals' choices respond to the way that they are framed, and our results confirm that voting is no exception. The very large effects found in the lower-profile races studied here indicate that, in low-information environments, framing can substantially influence these choices.

Our estimated effects are, in a way, both the same as those found in the two other studies of primary elections, and larger. In high-profile, high-information Republican up-ballot primaries, the ballot order effect of one to two percentage points resembles those found for similar elections by Koppell and Steen (2004) for New York City's 1998 Democratic Primary and by Ho and Imai (2008) for a range of California primaries. Similarly, our estimated effect for other state executive positions, three to five percentage points, resembles those of Ho and Imai (2008) for Attorney General and Controller. On the other hand, our findings for judicial elections are far exceed anything in the modern U.S. literature, for primary elections or anything else. The only comparable primaries studied, by Koppell and Steen (2004), are for local judges in New York City. There the effect is half as large.

The most prevalent theory of the ballot order effect is "satisficing": due to mental fatigue, voters choose the first acceptable option in down-ballot races, rather than choosing the candidate they most prefer. The simplest incarnation of this theory has four implications: 1) the ballot order effect should decline at a declining rate, 2 ) it should be positive for all ballot positions, relative to the last, 
3) the difference in the ballot order effect between successive ballot positions should not depend on the number of candidates, and 4) ballot order effects should be larger for more popular candidates. ${ }^{7}$ Only the first is supported in our estimates. Meredith and Salant (2013) also cast doubt on satisficing. Miller and Krosnick (1998, pp. 293-295) discuss psychological evidence for "primacy effects," which predispose individuals towards "selecting the first object considered in a set," arguing that they should be stronger when voters know less about candidates. Our results are consistent with primacy effects of this type: the magnitude of the ballot order effect is typically larger in less prominent contests that also feature lower campaign spending and more voter abstention. Like us, Brockington (2003) and Pasek et al. (2014) find that the ballot-order effect is larger when voters are less informed about the candidates in that contest, a finding confirmed in a recent experimental study by Kim, Krosnick, and Casasanto (2015).

Information could also explain differences in ballot order effects across election type. Miller and Krosnick argue that primacy effects should be larger "in races that do not offer voters heuristic cues, such as [the] party affiliations of the candidates." This would explain the smaller ballot order effects observed in studies of general elections. Similarly, the ballot order effect is somewhat smaller in runoffs, whose voters are fewer in number but probably better-informed. Conversely, it would also explain evidence (Ho and Imai, 2008; Chen et al., 2014) that the ballot order effect is somewhat larger in Presidential election years, which attract additional voters who are less-informed about down-ballot contests. The general implication of these findings is that the magnitude of ballot order

${ }^{7}$ If every candidate is equally likely to be acceptable to voters with probability $\mathrm{p}$, the ballot order effect in position $j=1 . . J$ equals $p(1-p)^{j-1}-p(1-p)^{J-1}$. One can easily confirm that this expression satisfies the first three implications, while the fourth follows whenever candidates are not all equally acceptable. 
effects can be quite context-specific. This point has been somewhat obscured by the dominance of general elections in the literature, and one focus of future studies should be to discern the magnitude of ballot order effects in arenas in which they are more likely to be substantial, as encouraged by Alvarez, Sinclair, and Hasen (2006).

In an ironic twist of fate, we were recently able to follow our own suggestion, with the March, 2016 Texas Republican primary, held just after the first draft of this paper was completed. Featuring a highly visible Presidential race, it drew twice as many voters as in 2014-and had contests for three Supreme Court positions, one of which was between Paul Green and Rick Green, two men with common first names and identical last names. ${ }^{8}$ It was The Perfect Storm, and our logic implies that this should lead to large ballot order effects. This is immediately evident in the histogram of county vote shares presented in Figure 2(a), without even looking at ballot order: in a race won with 52.1\% of the statewide vote, virtually no county's vote was nearly evenly split. Instead Paul Green's vote shares are bifurcated into two clusters, one around $40 \%$, and another around $60 \%$, suggesting a ballot order effect approaching twenty percentage points. The regression results in Figure 2(c) confirm this: the coefficient estimate is 19.4 percentage points. We have never seen a ballot order effect this large, and may never again.

Given the existence of sizeable ballot order effects, what should the uninformed voter do? The substantial ballot order effects in down-ballot races are matched by high rates of voter abstention, mentioned in Section 1. One argument for voter abstention is that it is wiser for the uninformed voter

${ }^{8}$ This was brought to the author's attention by Paul Hastings, campaign manager for the Rick Green campaign, shortly after the primary. Mr. Hastings generously volunteered (without conditions) preliminary ballot order data, taken from the web site described below; these data were checked for accuracy and supplemented by the author. Vote shares come from the Texas Secretary of State. 
to leave the final choice to the "wisdom of the crowd." The presence of ballot order effects, however, implies that the optimal choice is not to abstain, but to vote for the candidate furthest down the ballot. This helps to offset the ballot order effect, which obscures the crowd's wisdom. Meredith and Salant (2013, p. 193), in their study of thousands of local California elections, find that officials "who were elected from the first ballot position are more likely to lose in the next election," suggesting that candidates elected because of a boost from ballot position are indeed less effective.

Texas' randomization of ballot order should-if implemented as designed-largely cancel out ballot order effects at the state level, since candidates' mean ballot order will tend to converge. Still, some residual effects will linger, because ballot order will rarely be perfectly balanced and because the populations of Texas counties are quite skewed. ${ }^{9}$ Nonetheless, despite these effects and the absence of full randomization in the 2014 primaries and runoffs we analyzed, the final outcome was never effected. The winning margins were too large. This was true in the general election as well, despite the fact that ballot order there is not randomized. The partisan skew towards Republicans was far too large to be reversed by ballot order effects. Nonetheless, the size of the effects uncovered here is clearly large enough to justify some form of ballot order randomization or rotation in those states that have not yet adopted it, as argued by most papers in this literature.

The evidence of ballot manipulation in a few of the races we studied testifies to county chairs' belief that ballot order effects are genuine, a belief that is easily confirmed anecdotally by talking with politically active individuals in the state. Because of the size of the ballot order effect, especially in down-ballot races, reasonable steps should be taken to reduce the incidence of manipulation. One

9 The imbalance would be smaller when ballot order is systematically rotated across jurisdictions that are similar in population, as in the studies discussed in Section 1. Because this procedure is less decentralized, however, it is unlikely to be adopted in Texas. 
such step has already been taken: as of 2016, Texas' Secretary of State is now required to maintain a website that lists candidate filings by county, which should be entered by county chairs in ballot order, and from which the degree of randomization statewide can be more easily determined. ${ }^{10}$ Another simple step would be to modify Texas Elections Code 172.082 (e) to require more than twenty-four hours notice of a ballot order drawing. This would increase the chances that candidates can designate a representative to attend-a non-trivial feat, given Texas' size and remoteness, for candidates running statewide. In addition to these formal mechanisms are two informal mechanisms: public opinion, influenced in part by media coverage of an early draft of this paper across the state, and pressure on county chairs and executive committees from the state parties.

In our subjective view, the political process in Texas is surprisingly intimate and dynamic for a state of Texas' size and population and the many public offices filled by the power of the vote. The integrity of this process requires true randomization of ballot order across counties, so that its effects can even out to an appreciable degree. Otherwise the consequences could be substantial, because in Texas down-ballot primary elections, the ballot order effect is huge.

${ }^{10}$ The address is https://webservices.sos.state.tx.us/candidate-filing/cf-report.aspx. Most, though not all, chairs did enter candidates in ballot order. Though the statutory language implies this information should be archived, this was not done for the March, 2016 cycle. Doing so would provide additional accountability and a valuable database in the event of lawsuits. 


\section{REFERENCES}

Alvarez, R.M., B. Sinclair, and R. Hasen. "How Much Is Enough? The 'Ballot Order Effect' and the Use of Social Science Research in Election Law Disputes,” Election Law Journal 5:40-56 (2006).

Brockington, D. “A Low Information Theory of Ballot Position Effect," Political Behavior 25:1-27 (2003).

Chen, E., G. Simonovits, J. Krosnick, and J. Pasek. "The Impact of Candidate Name Order on Election Outcomes in North Dakota," Electoral Studies 35:115-122 (2014).

Darcy, R, and I. McAllister. "Ballot Position Effects,” Electoral Studies 9:5-17 (1990).

Fass, T., and H. Schoen. "The Importance of Being First: Effects of Candidates' List Positions in the 2003 Bavarian State Election," Electoral Studies 25:91:102 (2006).

Grant, D. "Searching for the Downsian Voter with a Simple Structural Model," Economics and Politics, 10, 2: 107-126 (1998).

Ho, D., and K. Imai. "Randomization Inference with Natural Experiments: An Analysis of Ballot effects in the 2003 California Recall Election," Journal of the American Statistical Association 101: 888-900 (2006).

----. "Estimating Causal Effects of Ballot Order from a Randomized Natural Experiment: The California Alphabet Lottery," Public Opinion Quarterly 72:216-240 (2008).

Jaeger, T. F. "Categorical Data Analysis: Away from ANOVAs (Transformation or Not) and Towards Mixed Models," Journal of Memory and Language 59:434-446 (2008).

Kim, N., J. Krosnick, and D. Casasanto. "Moderators of Candidate Name-Order Effects in Elections: An Experiment," Political Psychology 36:525-542 (2015).

King, A., and A. Leigh. “Are Ballot Order Effects Heterogenous?” Social Science Quarterly 90:7187 (2009).

Koppell, J., and J. Steen. “The Effects of Ballot Position on Election Outcomes," Journal of Politics 66:267-281 (2004).

Krosnick, J., J. Miller, and M. Tichy. "An Unrecognized Need for Ballot Reform: the Effects of Candidate Name Order on Election Outcomes," in Rethinking the Vote: The Politics and Prospects of American Election Reform, Oxford University Press, pp. $51-73$ (2004).

Lutz, G. "First Come, First Served: The Effect of Ballot Position on Electoral Success in Open Ballot PR Elections," Representation 46:167-181 (2010). 
Marcinkiewicz, K. "Electoral Contexts That Assist Voter Coordination: Ballot Position Effects in Poland," Electoral Studies 33:322-334 (2014).

Matsusaka, J. "Ballot Order Effects in Direct Democracy Elections," working paper, University of Southern California (2016).

Meredith, M., and V. Salant. "On the Causes and Consequences of Ballot Order Effects," Political Behavior 35:175-197 (2013).

Miller, J., and J. Krosnick. "The Impact of Candidate Name Order on Election Outcomes," Public Opinion Quarterly 62:291-330 (1998).

Pasek, J., D. Schneider, J. Krosnick, A. Tahk, E. Ophir, and C. Milligan. "Prevalence and Moderators of the Candidate Name-Order Effect: Evidence from Statewide General Elections in California," Public Opinion Quarterly, 78:416-439 (2014). 


\section{Appendix A: Weighting.}

The table below compares simulated weights with the approximation used in this paper. In the simulations, a latent variable, "candidate popularity," is assumed to be normally distributed across counties with a specified mean and standard deviation. This popularity is treated as the probability that each voter within each county votes for that candidate. From these assumptions the variance of vote shares in different sized electorates is easily calculated.

Scenario One (see note)

Scenario Two (see note)

\begin{tabular}{|c|c|c|c|c|c|c|c|}
\hline $\begin{array}{l}\text { Number of } \\
\text { Voters }\end{array}$ & $\begin{array}{l}\text { Formula } \\
\text { Weights }\end{array}$ & $\begin{array}{c}\text { Candidate A: } \\
\text { Preferred by } \\
45 \% \text { of the } \\
\text { Electorate }\end{array}$ & $\begin{array}{l}\text { Candidate B } \\
\text { Preferred by } \\
30 \% \text { of the } \\
\text { Electorate }\end{array}$ & $\begin{array}{c}\text { Candidate C: } \\
\text { Preferred by } \\
15 \% \text { of the } \\
\text { Electorate }\end{array}$ & $\begin{array}{l}\text { Candidate A: } \\
\text { Preferred by } \\
45 \% \text { of the } \\
\text { Electorate }\end{array}$ & $\begin{array}{c}\text { Candidate B: } \\
\text { Preferred by } \\
30 \% \text { of the } \\
\text { Electorate }\end{array}$ & $\begin{array}{c}\text { Candidate C: } \\
\text { Preferred by } \\
15 \% \text { of the } \\
\text { Electorate }\end{array}$ \\
\hline 25 & 0.70 & 0.53 & 0.57 & 0.71 & 0.69 & 0.73 & 0.84 \\
\hline 100 & 1.00 & 0.94 & 1.00 & 1.17 & 0.97 & 1.00 & 1.06 \\
\hline 500 & 1.35 & 1.47 & 1.51 & 1.61 & 1.14 & 1.15 & 1.17 \\
\hline 2000 & 1.65 & 1.71 & 1.73 & 1.76 & 1.18 & 1.18 & 1.19 \\
\hline $\begin{array}{l}\text { correlation with } \\
\text { formula }\end{array}$ & 1.00 & 0.99 & 0.99 & 0.99 & 0.96 & 0.95 & 0.93 \\
\hline
\end{tabular}

Note: In Scenario One, county random effects have a standard deviation of three percentage points, and there are four candidates: Candidate $\mathrm{A}$ is preferred by $45 \%$ of the electorate (though not necessarily $45 \%$ of all votes cast), Candidate $\mathrm{B}$ is preferred by $30 \%$ of the electorate, Candidate $\mathrm{C}$ is preferred by $15 \%$ of the electorate, and Candidate $\mathrm{D}$, who is preferred by $10 \%$ of the electorate, is omitted from the regression analysis. In Scenario Two, county random effects have a standard deviation of seven percentage points, and there are the same four candidates as before. In both scenarios, weights are normalized so that they equal one for Candidate B in a one-hundred vote election. 


\section{Appendix B. Implications of Elections Being Zero Sum for the Ballot Order Effect.}

The demonstration is conducted for a three-candidate election, and can be extended by induction. Allowing the ballot order effect to differ across candidates yields the following system:

$$
\begin{aligned}
& S_{1}=\alpha_{1}+\beta_{1} F I R S T_{1}+\gamma_{1} S_{1 C O N D_{1}+\varepsilon_{1}} \\
& S_{2}=\alpha_{2}+\beta_{2} F I R S T_{2}+\gamma_{2} S E C O N D_{2}+\varepsilon_{2} \\
& S_{3}=\alpha_{3}+\beta_{3} F I R S T_{3}+\gamma_{3} S E C O N D_{3}+\varepsilon_{3}
\end{aligned}
$$

where S indicates the candidate's vote share, FIRST is a dummy for being listed first on the ballot, SECOND is a dummy for being listed second on the ballot, $\alpha, \beta$, and $\gamma$ are coefficients, and $\varepsilon$ is an error term. The subscripts 1,2 , and 3 refer to the three candidates in the election.

For elections to be a zero sum game, any re-arrangement of ballot order should not be predicted to increase the total vote share, $\mathrm{S}_{1}+\mathrm{S}_{2}+\mathrm{S}_{3}$, which must equal one. Assuming the system above and an initial ballot order of 1, 2, 3, the following re-arrangements of ballot order imply the following changes in total vote share, which must equal zero for elections to be zero-sum:

$$
\begin{array}{rrr}
- & 2,1,3: & -\beta_{1}+\beta_{2}+\gamma_{1}-\gamma_{2}=0 \\
\text { - } & 3,2,1: & -\beta_{1}+\beta_{3}=0 \\
\text { - } & 2,3,1: & -\beta_{1}+\beta_{2}+\gamma_{2}-\gamma_{3}=0 \\
\text { - } & 1,3,2: & -\gamma_{2}+\gamma_{3}=0 \\
& 3,1,2: & -\beta_{1}+\beta_{3}+\gamma_{1}-\gamma_{2}=0
\end{array}
$$

It is a simple matter to verify that these restrictions together imply that $\beta_{1}=\beta_{2}=\beta_{3}$ and $\gamma_{1}=\gamma_{2}=\gamma_{3}$.

\section{Appendix C. Bias Correction Using Other Races' Ballot Order.}

For simplicity, imagine two, two candidate races, Race 1 and Race 2. Evidence indicates that the "establishment" candidate is favored in the ballot order in Race 1. Let $\mathrm{F}^{1}$ equal a dummy variable indicating whether this candidate is listed first on the ballot. Then:

$$
P\left(F_{c}^{1}=1\right)=\frac{1}{2}+\frac{B_{c}}{2}, \quad B_{c} \in\{0,1\}
$$

where $\mathrm{c}$ indexes counties, and $\mathrm{B}$ is an indicator variable indicating whether the county chair favors the establishment candidate in determining ballot order. If this candidate is listed second on county c's ballot, $B_{c}=0$. If they are listed first, one can easily show that $P\left(B_{c}=1\right)=2-1 / E\left(F^{1}\right)$, with the expectation taken across all counties.

In Race 2, Adams is also the "establishment" candidate, though county chairs may be more or less likely to favor Adams in determining ballot order than they were in Race 1. Setting aside all controls, the vote share of Adams in Race 2, A, is determined as follows:

$$
A_{c}=\alpha+\beta F_{c}^{2}+\left(\varphi B_{c}+\varepsilon_{c}\right)
$$

where $\mathrm{F}^{2}$ is a dummy variable indicating whether Adams is listed first on the ballot and $\varepsilon$ is an error 
term. The unobserved term $\varphi B_{c}$ reflects potential bias introduced when county chairs' favoritism in determining ballot order is related to Adams' popularity in that county.

Then:

$$
\begin{gathered}
E\left(A_{c} \mid F^{1}=0, F^{2}=0\right)=\alpha \\
E\left(A_{c} \mid F^{1}=1, F^{2}=0\right)=\alpha+\varphi\left[2-1 / E\left(F^{1}\right)\right] \\
E\left(A_{c} \mid F^{1}=0, F^{2}=1\right)=\alpha+\beta \\
E\left(A_{c} \mid F^{1}=1, F^{2}=1\right)=\alpha+\beta+\varphi\left[2-1 / E\left(F^{1}\right)\right]
\end{gathered}
$$

Is it easy to confirm that $\mathrm{E}\left(\mathrm{A} \mid \mathrm{F}^{1}=1, \mathrm{~F}^{2}=1\right)-\mathrm{E}\left(\mathrm{A} \mid \mathrm{F}^{1}=1, \mathrm{~F}^{2}=0\right)=\mathrm{E}\left(\mathrm{A} \mid \mathrm{F}^{1}=0, \mathrm{~F}^{2}=1\right)-\mathrm{E}\left(\mathrm{A} \mid \mathrm{F}^{1}=0, \mathrm{~F}^{2}\right.$ $=0)=\beta$. Thus, under these assumptions, the following regression yields unbiased estimates of $\beta$ :

$$
A_{c}=\alpha+\beta F_{c}^{2}+\lambda F_{c}^{1}+\varepsilon_{c}
$$

This regression, with controls, generates the bracketed estimates presented in Table 5. 
Table 1. Summary of the post-1995 Literature on Ballot Order Effects in the U.S.

OFFICE CONTESTED

\begin{tabular}{|c|c|c|c|c|c|c|}
\hline Election Date & Federal & $\begin{array}{l}\text { State } \\
\text { Executive }\end{array}$ & $\begin{array}{l}\text { State } \\
\text { Legislative }\end{array}$ & $\begin{array}{l}\text { State } \\
\text { Judicial }\end{array}$ & Local & Party Position \\
\hline General & $\begin{array}{l}\text { CA-unknown } \\
\text { CA-small } \\
\text { CA-small } \\
\text { CA-small } \\
\text { ND-small } \\
\text { ND-small } \\
\text { OH-small } \\
\text { OH-small }\end{array}$ & $\begin{array}{l}\text { CA-unknown } \\
\text { CA-small } \\
\text { CA-small } \\
\text { ND-small } \\
\text { ND-small } \\
\text { OH-small } \\
\text { OH-small }\end{array}$ & & $\begin{array}{l}\text { ND-medium } \\
\text { (non-partisan) }\end{array}$ & OH-small & \\
\hline Primary & $\begin{array}{l}\text { CA-small } \\
\text { NY-small }\end{array}$ & $\begin{array}{l}\text { CA-medium } \\
\text { NY-small } \\
\text { this study }\end{array}$ & NY-small & this study & NY-small & NY-medium \\
\hline Runoff & & this study & & & & \\
\hline Local & & & & & $\begin{array}{l}\text { CA-medium } \\
\text { IL-medium (at large) } \\
\text { large (cumulative } \\
\text { voting) }\end{array}$ & \\
\hline Recall & & CA-small & & & & \\
\hline
\end{tabular}

Note: Small indicates a first-position ballot order effect of less than 3.0 percentage points; med indicates a ballot order effect of 3.0-6.0 percentage points, large indicates a ballot order effect exceeding 6.0 percentage points. The magnitude of the estimates in one study of California general elections could not be classified. Each entry is a state within a study; thus any given study may be entered more than once in the table or even within an individual cell, if it studied multiple states. 
Table 2. Ballot Receipt.

\begin{tabular}{|c|c|c|c|}
\hline & $\begin{array}{l}\text { Ballots Received / } \\
\text { Elections Held }\end{array}$ & Omitted Counties & $\begin{array}{c}\text { approximate } 25^{\text {th }}, 50^{\text {th }} \text {, and } \\
75^{\text {th }} \text { percentiles of } \\
\text { population (votes) }\end{array}$ \\
\hline $\begin{array}{l}\text { Democratic } \\
\text { Primary }\end{array}$ & $\begin{array}{c}233 / 233 \\
(100 \%)\end{array}$ & & $\begin{array}{l}8,700 ; 20,700 ; 53,800 \\
(116 ; 381 ; 1187)\end{array}$ \\
\hline $\begin{array}{l}\text { Republican } \\
\text { Primary }\end{array}$ & $\begin{array}{l}245 / 246 \\
(99.6 \%)\end{array}$ & Dimmitt & $\begin{array}{l}6,700 ; 19,300 ; 50,800 \\
\quad(648 ; 1662 ; 4879)\end{array}$ \\
\hline $\begin{array}{l}\text { Democratic } \\
\text { Runoff(see note) }\end{array}$ & $\begin{array}{l}222 / 230 \\
(96.5 \%)\end{array}$ & $\begin{array}{l}\text { Blanco, Dimmitt, } \\
\text { Hudspeth, Kinney, Loving, } \\
\text { Reeves, San Saba, Uvalde }\end{array}$ & $\begin{array}{c}9,000 ; 20,700 ; 54,400 \\
(27 ; 87 ; 303)\end{array}$ \\
\hline $\begin{array}{l}\text { Republican } \\
\text { Runoff }\end{array}$ & $\begin{array}{c}238 / 245 \\
(97.1 \%)\end{array}$ & $\begin{array}{l}\text { Blanco, Dimmitt, Loving, } \\
\text { Lynn, McMullen, Sutton, } \\
\text { Uvalde }\end{array}$ & $\begin{array}{l}6,700 ; 19,400 ; 50,800 \\
\quad(252 ; 710 ; 2307)\end{array}$ \\
\hline
\end{tabular}

Note: The Democratic runoff held in Sterling County apparently had no voters. It was thus omitted from the ballot order effect regressions, but included in the randomization analysis. The number of votes is approximate, based on the number of votes recorded in the race on that ballot with the fewest abstentions statewide. 
Table 3. Descriptive Statistics on the Control Variables.

\begin{tabular}{|c|c|c|c|}
\hline Variable & Unweighted Mean & Median & Standard Deviation \\
\hline Population (thousands) & 99.0 & 18.4 & 352.9 \\
\hline Percent Anglo & 81.1 & 82.1 & 8.6 \\
\hline Percent Black & 6.3 & 3.9 & 6.7 \\
\hline Percent Hispanic & 32.3 & 24.0 & 22.9 \\
\hline Land Area (sq. mi.) & $1,028.5$ & 908.7 & 658.6 \\
\hline $\begin{array}{l}\text { Per Capita Income } \\
\text { (\$ thousands) }\end{array}$ & 39.1 & 37.0 & 9.2 \\
\hline Mean Annual Rainfall (in.) & 32.1 & 30.2 & 12.0 \\
\hline $\begin{array}{l}\text { Value of Agricultural } \\
\text { Products (\$ millions) }\end{array}$ & 99.7 & 45.9 & 194.4 \\
\hline Unemployment & 4.9 & 4.7 & 1.7 \\
\hline $\begin{array}{l}\text { Percentage of Housing } \\
\text { That Is Owner-Occupied }\end{array}$ & 72.4 & 73.7 & 7.2 \\
\hline Median Age in Years & 39.1 & 38.5 & 5.9 \\
\hline $\begin{array}{l}\text { Percent of } 25+\text { Year-Olds } \\
\text { Graduated High School }\end{array}$ & 78.3 & 80.0 & 8.1 \\
\hline $\begin{array}{l}\text { Percent of } 25+\text { Year-Olds } \\
\text { Graduated College }\end{array}$ & 17.7 & 16.0 & 7.2 \\
\hline $\begin{array}{l}\text { Votes for John McCain in } \\
2012 \text { (thousands) }\end{array}$ & 18.0 & 4.2 & 53.2 \\
\hline $\begin{array}{l}\text { Votes for Barack Obama in } \\
2012 \text { (thousands) }\end{array}$ & 13.0 & 1.7 & 53.6 \\
\hline $\begin{array}{l}\text { Total Registered Voters } \\
\text { (thousands) }\end{array}$ & 53.5 & 10.8 & 179.2 \\
\hline
\end{tabular}

Note: for variable sources and approximate vintages, see the text. 
Table 4. Randomization Tests.

4a: Two Candidate Races

\begin{tabular}{|c|c|c|c|c|}
\hline $\begin{array}{l}\text { Election } \\
\text { Contest }\end{array}$ & $\begin{array}{l}\text { Winning } \\
\text { Candidate }\end{array}$ & $\begin{array}{l}\text { Fraction This } \\
\text { Candidate } \\
\text { Listed First on } \\
\text { the Ballot }\end{array}$ & $\begin{array}{l}\text { Chi-Squared } \\
\text { Test of Null } \\
\text { This Fraction is } \\
0.5 \text { (p-value) }\end{array}$ & $\begin{array}{l}\text { Likelihood-Ratio } \\
\text { Test: Irrelevance } \\
\text { of Independent } \\
\text { Variables (p-value) }\end{array}$ \\
\hline \multicolumn{5}{|l|}{ Democratic Primary } \\
\hline Governor & Davis & 0.55 & 0.10 & 0.11 \\
\hline Railroad Comm. & S. Brown & 0.52 & 0.60 & 0.04 \\
\hline \multicolumn{5}{|l|}{ Republican Primary } \\
\hline Land Comm. & Bush & 0.49 & 0.75 & 0.77 \\
\hline $\begin{array}{l}\text { Supreme Court } \\
\text { Chief Justice }\end{array}$ & Hecht & 0.57 & 0.04 & 0.33 \\
\hline $\begin{array}{l}\text { Supreme Court } \\
\text { Place } 6\end{array}$ & J. Brown & 0.49 & 0.80 & 0.66 \\
\hline $\begin{array}{l}\text { Supreme Court } \\
\text { Place } 8\end{array}$ & Johnson & 0.49 & 0.80 & 0.05 \\
\hline $\begin{array}{l}\text { Court Crim. App. } \\
\text { Place } 3\end{array}$ & Richardson & 0.51 & 0.75 & 0.23 \\
\hline $\begin{array}{l}\text { Court Crim. App. } \\
\text { Place } 9\end{array}$ & Newell & 0.50 & 0.90 & 0.77 \\
\hline \multicolumn{5}{|l|}{ Democratic Runoff } \\
\hline U.S. Senator & Alameel & 0.73 & 0.00 & 0.92 \\
\hline $\begin{array}{l}\text { Agriculture } \\
\text { Comm. }\end{array}$ & Hogan & 0.45 & 0.04 & 0.76 \\
\hline \multicolumn{5}{|l|}{ Republican Runoff } \\
\hline Attorney General & Paxton & 0.49 & 0.80 & 0.64 \\
\hline Lieutenant Gov. & Patrick & 0.48 & 0.52 & 0.04 \\
\hline Railroad Comm. & Sitton & 0.53 & 0.30 & 0.47 \\
\hline $\begin{array}{l}\text { Agriculture } \\
\text { Comm. }\end{array}$ & Miller & 0.47 & 0.30 & 0.24 \\
\hline
\end{tabular}


4b: Multi-Candidate Races. Proportion listed first on the ballot, with the p-value of the $\chi^{2}$ test of the null that ballot position is assigned randomly in parentheses, and the p-value of the likelihood ratio test of the null that ballot position is unrelated to the vote share analysis' control variables in brackets.

\begin{tabular}{|c|c|c|c|c|}
\hline $\begin{array}{l}\text { Election } \\
\quad \text { Contest } \\
\text { (candidate count) }\end{array}$ & $\begin{array}{l}\text { Leading } \\
\text { Candidate }\end{array}$ & Runner Up & $\begin{array}{l}\text { Second } \\
\text { Runner Up }\end{array}$ & $\begin{array}{l}\text { Third } \\
\text { Runner Up }\end{array}$ \\
\hline $\begin{array}{l}\text { Democratic Primary } \\
\text { U.S. Senator } \\
\text { (five candidates) }\end{array}$ & $\begin{array}{c}0.28 \\
(0.00) \\
{[0.98]}\end{array}$ & $\begin{array}{c}0.15 \\
(0.00) \\
{[0.12]}\end{array}$ & $\begin{array}{c}0.18 \\
(0.01) \\
{[0.63]}\end{array}$ & $\begin{array}{c}0.18 \\
(0.69) \\
{[0.36]}\end{array}$ \\
\hline $\begin{array}{l}\text { Agriculture Comm. }{ }^{\S} \\
\text { (three candidates) }\end{array}$ & $\begin{array}{c}0.36 \\
(0.59) \\
{[0.90]}\end{array}$ & $\begin{array}{c}0.27 \\
(0.11) \\
{[0.87]}\end{array}$ & $\begin{array}{c}0.36 \\
(0.52) \\
{[0.86]}\end{array}$ & \\
\hline $\begin{array}{l}\text { Republican Primary } \\
\text { U.S. Senator } \\
\text { (eight candidates) }\end{array}$ & $\begin{array}{c}0.13 \\
(0.19) \\
{[0.44]}\end{array}$ & $\begin{array}{c}0.16 \\
(0.01) \\
{[0.69]}\end{array}$ & $\begin{array}{c}0.12 \\
(0.00) \\
{[1.00]}\end{array}$ & $\begin{array}{l}0.10 \\
(0.17) \\
{[0.66]}\end{array}$ \\
\hline $\begin{array}{l}\text { U.S. Senator: } \\
\text { Candidates 5-8 }\end{array}$ & $\begin{array}{c}0.09 \\
(0.21) \\
{[0.23]}\end{array}$ & $\begin{array}{c}0.20 \\
(0.03) \\
{[0.94]}\end{array}$ & $\begin{array}{l}0.08 \\
(0.10) \\
{[0.57]}\end{array}$ & $\begin{array}{c}0.12 \\
(0.09) \\
{[0.69]}\end{array}$ \\
\hline $\begin{array}{l}\text { Governor } \\
\text { (four candidates) }\end{array}$ & $\begin{array}{c}0.32 \\
(0.00) \\
{[0.31]}\end{array}$ & $\begin{array}{l}0.23 \\
(0.35) \\
{[0.15]}\end{array}$ & $\begin{array}{c}0.20 \\
(0.03) \\
{[0.81]}\end{array}$ & $\begin{array}{l}0.25 \\
(0.15) \\
{[0.53]}\end{array}$ \\
\hline $\begin{array}{l}\text { Lt. Governor } \\
\text { (four candidates) }\end{array}$ & $\begin{array}{c}0.31 \\
(0.13) \\
{[0.30]}\end{array}$ & $\begin{array}{l}0.25 \\
(0.03) \\
{[0.08]}\end{array}$ & $\begin{array}{c}0.20 \\
(0.06) \\
{[0.13]}\end{array}$ & $\begin{array}{c}0.24 \\
(0.37) \\
{[0.05]}\end{array}$ \\
\hline $\begin{array}{l}\text { Attorney General }{ }^{\S} \\
\text { (three candidates) }^{\text {a }}\end{array}$ & $\begin{array}{c}0.31 \\
(0.30) \\
{[0.77]}\end{array}$ & $\begin{array}{c}0.35 \\
(0.30) \\
{[0.63]}\end{array}$ & $\begin{array}{c}0.35 \\
(0.27) \\
{[0.48]}\end{array}$ & \\
\hline $\begin{array}{l}\text { Comptroller } \\
\text { (four candidates) }\end{array}$ & $\begin{array}{c}0.25 \\
(0.63) \\
{[0.10]}\end{array}$ & $\begin{array}{c}0.21 \\
(0.07) \\
{[0.02]}\end{array}$ & $\begin{array}{c}0.26 \\
(0.76) \\
{[0.74]}\end{array}$ & $\begin{array}{c}0.28 \\
(0.64) \\
{[0.18]}\end{array}$ \\
\hline $\begin{array}{l}\text { Agriculture Comm. } \\
\text { (five candidates) }\end{array}$ & $\begin{array}{c}0.22 \\
(0.46) \\
{[0.85]}\end{array}$ & $\begin{array}{c}0.18 \\
(0.40) \\
{[0.44]}\end{array}$ & $\begin{array}{l}0.20 \\
(0.60) \\
{[0.34]}\end{array}$ & $\begin{array}{l}0.19 \\
(0.32) \\
{[0.75]}\end{array}$ \\
\hline $\begin{array}{l}\text { Railroad Comm. } \\
\text { (four candidates) }\end{array}$ & $\begin{array}{c}0.18 \\
(0.00) \\
{[0.85]}\end{array}$ & $\begin{array}{c}0.26 \\
(0.48) \\
{[0.18]}\end{array}$ & $\begin{array}{c}0.29 \\
(0.54) \\
{[0.28]}\end{array}$ & $\begin{array}{c}0.28 \\
(0.55) \\
{[0.22]}\end{array}$ \\
\hline
\end{tabular}


Court Criminal

Appeals Place $4^{\dagger}$

(three candidates)
0.28

$(0.00)$

$[0.34]$
0.41

$(0.02)$

$[0.20]$
0.31

[0.22]

* signifies that Fisher's exact test did not compute a solution (see the text).

$\S$ signifies that Fisher's exact test did not reject the null hypothesis of random ballot order determination at a $10 \%$ level of significance.

${ }^{\dagger}$ signifies that Fisher's exact test rejected the null hypothesis of random ballot order determination at a $1 \%$ level of significance. 
Table 5. Estimates of the Ballot Order Effect on Candidates' Percentage of the Vote (SUR coefficient estimates in the center of each cell, with estimates without controls in parentheses, and estimates that also control for other races' ballot order in brackets).

\begin{tabular}{|c|c|c|c|c|c|}
\hline & $\begin{array}{c}\text { First } \\
\text { Position }\end{array}$ & $\begin{array}{l}\text { Second } \\
\text { Position }\end{array}$ & $\begin{array}{l}\text { Third } \\
\text { Position }\end{array}$ & $\begin{array}{l}\text { Fourth } \\
\text { Position }\end{array}$ & $\begin{array}{c}\text { Approx. } \\
\text { Standard } \\
\text { Error }\end{array}$ \\
\hline $\begin{array}{l}\text { Democratic Primary } \\
\text { U.S. Senator }\end{array}$ & $\begin{array}{c}(5.46) \\
5.95 \\
{[5.61]}\end{array}$ & $\begin{array}{c}(1.51) \\
1.31 \\
{[1.24]}\end{array}$ & $\begin{array}{c}(1.06) \\
0.92 \\
{[0.60]}\end{array}$ & $\begin{array}{c}(-0.77) \\
-0.69 \\
{[-0.80]}\end{array}$ & $\begin{array}{c}(0.53) \\
0.52 \\
{[0.52]}\end{array}$ \\
\hline Governor & $\begin{array}{c}(7.83) \\
4.02 \\
{[4.11]}\end{array}$ & 0 & & & $\begin{array}{c}(2.37) \\
1.14 \\
{[1.17]}\end{array}$ \\
\hline Agriculture Comm. & $\begin{array}{c}(4.24) \\
4.68 \\
{[4.63]}\end{array}$ & $\begin{array}{c}(1.73) \\
1.89 \\
{[1.93]}\end{array}$ & 0 & & $\begin{array}{c}(0.82) \\
0.71 \\
{[0.71]}\end{array}$ \\
\hline Railroad Comm. & $\begin{array}{c}(7.44) \\
7.39 \\
{[7.52]} \\
\end{array}$ & 0 & & & $\begin{array}{c}(0.95) \\
0.87 \\
{[0.90]}\end{array}$ \\
\hline $\begin{array}{l}\text { Republican Primary } \\
\text { U.S. Senator }\end{array}$ & $\begin{array}{c}(1.50) \\
1.49 \\
{[1.42]}\end{array}$ & $\begin{array}{c}(0.10) \\
0.22 \\
{[0.17]}\end{array}$ & $\begin{array}{c}(0.07) \\
0.07 \\
{[0.03]}\end{array}$ & $\begin{array}{c}(-0.07) \\
-0.05 \\
{[-0.08]}\end{array}$ & $\begin{array}{c}(0.13) \\
0.13 \\
{[0.13]}\end{array}$ \\
\hline $\begin{array}{l}\text { U.S. Senator: Ballot } \\
\text { Positions 5-8 }\end{array}$ & $\begin{array}{c}(0.08) \\
0.05 \\
{[0.00]}\end{array}$ & $\begin{array}{c}(-0.40) \\
-0.34 \\
{[-0.39]}\end{array}$ & $\begin{array}{c}(-0.28) \\
-0.27 \\
{[-0.31]}\end{array}$ & 0 & $\begin{array}{c}(0.13) \\
0.13 \\
{[0.13]}\end{array}$ \\
\hline Governor & $\begin{array}{c}(0.54) \\
0.52\end{array}$ & $\begin{array}{l}(-0.10) \\
-0.03\end{array}$ & $\begin{array}{l}(-0.09) \\
-0.10\end{array}$ & 0 & $\begin{array}{c}(0.18) \\
0.15\end{array}$ \\
\hline Lt. Governor & $\begin{array}{c}(1.78) \\
2.00\end{array}$ & $\begin{array}{c}(1.13) \\
1.42\end{array}$ & $\begin{array}{c}(-0.29) \\
0.23\end{array}$ & 0 & $\begin{array}{c}(0.73) \\
0.60\end{array}$ \\
\hline Attorney General & $\begin{array}{c}(4.63) \\
4.69 \\
{[4.60]}\end{array}$ & $\begin{array}{c}(1.98) \\
1.31 \\
{[1.25]}\end{array}$ & 0 & & $\begin{array}{c}(0.66) \\
0.60 \\
{[0.61]}\end{array}$ \\
\hline Comptroller & $\begin{array}{c}(3.23) \\
2.88 \\
{[2.98]}\end{array}$ & $\begin{array}{c}(1.72) \\
1.12 \\
{[1.17]}\end{array}$ & $\begin{array}{c}(0.79) \\
0.47 \\
{[0.64]}\end{array}$ & 0 & $\begin{array}{c}(0.55) \\
0.46 \\
{[0.46]}\end{array}$ \\
\hline Land Commissioner & $\begin{array}{c}(2.28) \\
2.18 \\
{[2.16]}\end{array}$ & 0 & & & $\begin{array}{c}(0.59) \\
0.52 \\
{[0.52]}\end{array}$ \\
\hline
\end{tabular}




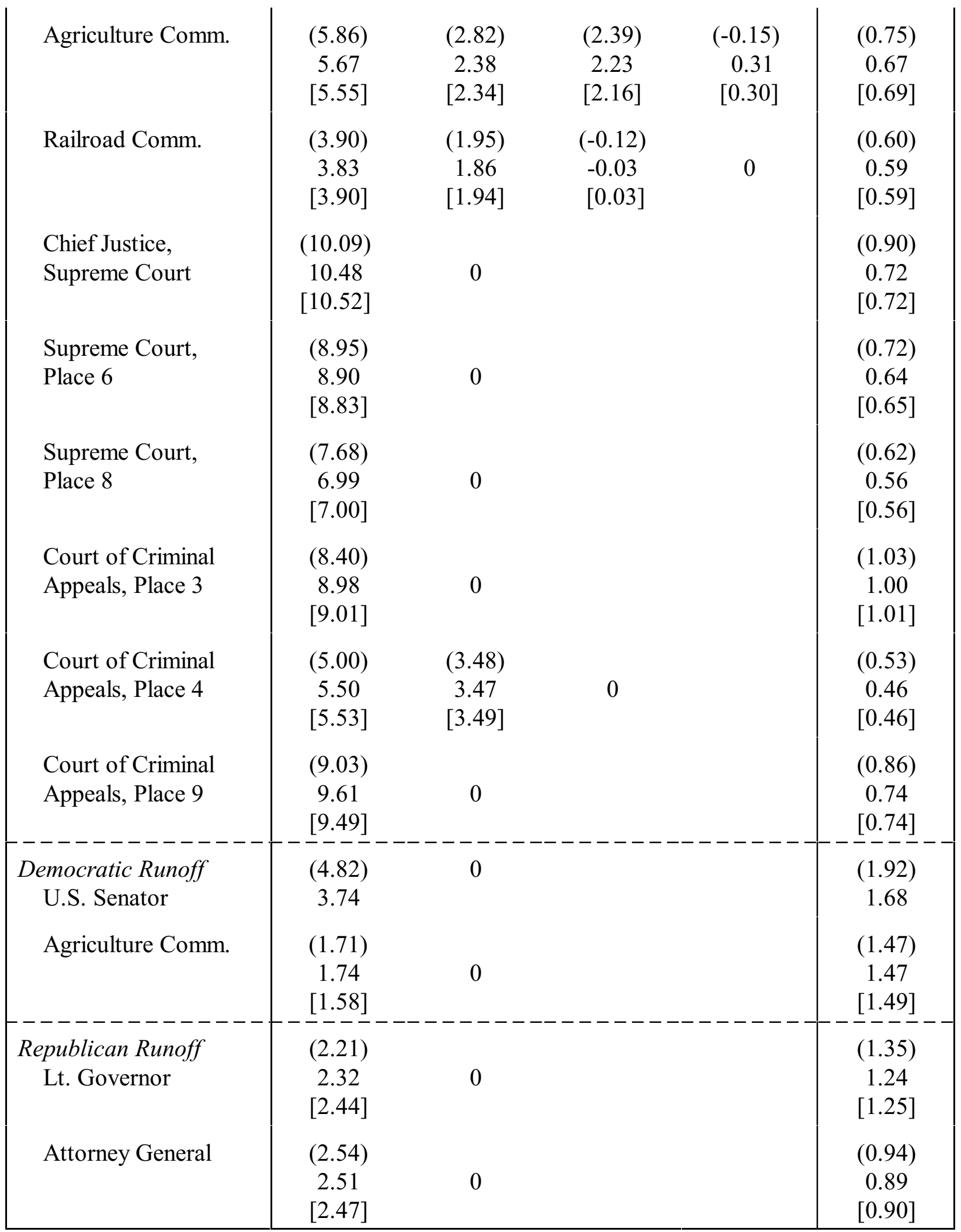




\begin{tabular}{|l|ccc|c|} 
Agriculture Comm. & $(5.36)$ & & $(1.37)$ \\
& 5.25 & 0 & 1.17 \\
& {$[5.41]$} & & {$[1.18]$} \\
Railroad Comm. & $(3.78)$ & & $(1.08)$ \\
& 3.40 & 0 & 1.00 \\
& {$[3.42]$} & & {$[1.01]$} \\
\hline
\end{tabular}

Note: The last position on the ballot is indicated with a zero. If a zero is missing, the race had five candidates. The bracketed estimates control for ballot position in the Democratic Senatorial Runoff, for Democratic races, and for Republican races, dummies for whether Greg Abbott was listed first on the ballot for Governor, and whether Dan Patrick was listed first on the ballot for Lt. Governor. 
Table 6. Interactions of the Being Listed First on the Ballot with Demographic and Economic Variables, All Two Candidate Races (coefficient estimates on interaction terms, with $5 \%$ significance indicated with * and $10 \%$ with **).

INTERACTION TERMS ON VOTE SHARE IN PERCENTAGE POINTS

\begin{tabular}{|c|c|c|c|c|c|c|c|c|}
\hline $\begin{array}{l}\text { Election } \\
\text { Contest }\end{array}$ & $\begin{array}{l}\text { Percent } \\
\text { Anglo }\end{array}$ & $\begin{array}{l}\text { Per Capita } \\
\text { Income, in } \\
\text { Thousands }\end{array}$ & $\begin{array}{l}\text { Percent of } \\
\text { Households } \\
\text { Own Home }\end{array}$ & $\begin{array}{l}\text { Median } \\
\text { Age in } \\
\text { Years }\end{array}$ & $\begin{array}{l}\text { Percent } \\
\text { Graduated } \\
\text { High Sch. }\end{array}$ & $\begin{array}{l}\text { Percent } \\
\text { Graduated } \\
\text { College }\end{array}$ & $\begin{array}{l}\text { Log of } \\
\text { Population }\end{array}$ & $\begin{array}{l}\text { Log of } \\
\text { Area }\end{array}$ \\
\hline \multicolumn{9}{|l|}{ Democratic Primary } \\
\hline Governor & -0.24 & 0.08 & 0.23 & 0.46 & $1.27 *$ & 0.15 & $2.77 *$ & 3.24 \\
\hline Railroad Comm. & $-0.48^{*}$ & -0.11 & $0.21 * *$ & -0.29 & -0.05 & 0.27 & $-1.20 * *$ & 1.11 \\
\hline \multicolumn{9}{|l|}{ Republican Primary } \\
\hline Land Comm. & $0.15^{*}$ & $0.20 *$ & $-0.30 *$ & -0.04 & -0.13 & $-0.23 *$ & $0.73 * *$ & $-2.80 *$ \\
\hline $\begin{array}{l}\text { Supreme Court } \\
\text { Chief Justice }\end{array}$ & 0.11 & $0.14 *$ & $-0.25 *$ & 0.06 & $-0.22 * *$ & $0.23 *$ & 0.61 & -1.89 \\
\hline $\begin{array}{l}\text { Supreme Court } \\
\text { Place } 6\end{array}$ & -0.11 & 0.07 & -0.03 & -0.10 & 0.07 & 0.04 & -0.60 & 0.32 \\
\hline $\begin{array}{l}\text { Supreme Court } \\
\text { Place } 8\end{array}$ & -0.08 & 0.06 & $-0.17 *$ & 0.09 & -0.04 & -0.06 & $-1.08^{*}$ & 0.50 \\
\hline $\begin{array}{l}\text { Court Criminal } \\
\text { App. Place } 3\end{array}$ & -0.16 & 0.11 & -0.15 & 0.17 & 0.14 & $-0.33^{*}$ & 2.69 & 0.71 \\
\hline $\begin{array}{l}\text { Court Criminal } \\
\text { App. Place } 9\end{array}$ & -0.02 & -0.04 & -0.17 & 0.02 & 0.10 & -0.15 & $-1.84 *$ & -1.64 \\
\hline \multicolumn{9}{|l|}{ Democratic Runoff } \\
\hline U.S. Senator & $0.47 *$ & $0.51 *$ & -0.14 & 0.15 & -0.31 & -0.02 & $4.61^{*}$ & -1.32 \\
\hline
\end{tabular}




\begin{tabular}{|c|c|c|c|c|c|c|c|c|}
\hline $\begin{array}{l}\text { Agriculture } \\
\text { Comm. }\end{array}$ & 0.11 & -0.00 & 0.05 & 0.42 & $-0.59^{*}$ & 0.41 & 1.34 & -3.49 \\
\hline \multicolumn{9}{|l|}{ Republican Runoff } \\
\hline Lieutenant Gov. & $0.42^{*}$ & $-0.26^{*}$ & $-0.43 *$ & 0.41 & $-0.58^{*}$ & $0.35^{*}$ & 0.43 & -4.27 \\
\hline Attorney General & $0.32 *$ & 0.02 & $-0.61^{*}$ & $0.39^{*}$ & $-0.46^{*}$ & 0.03 & -0.41 & $-3.43 * *$ \\
\hline Railroad Comm. & 0.08 & -0.20 & 0.22 & 0.03 & 0.12 & -0.07 & 0.48 & -2.09 \\
\hline $\begin{array}{l}\text { Agriculture } \\
\text { Commissioner }\end{array}$ & -0.05 & $-0.27 *$ & 0.10 & -0.08 & 0.16 & -0.26 & 0.89 & -1.75 \\
\hline Median Estimate & 0.03 & 0.01 & -0.15 & 0.08 & -0.04 & -0.04 & 0.46 & -1.82 \\
\hline $\begin{array}{l}\text { Standard Deviation } \\
\text { of Independent } \\
\text { Variable }\end{array}$ & 8.58 & 9.21 & 7.23 & 5.87 & 8.14 & 7.22 & 1.67 & 0.47 \\
\hline $\begin{array}{l}\text { Median Effect of a } \\
\text { One Standard } \\
\text { Deviation Change } \\
\text { (percentage points) }\end{array}$ & 0.26 & 0.09 & -1.08 & 0.44 & -0.37 & 0.29 & 0.76 & -0.50 \\
\hline
\end{tabular}


Figure 1. Sample Primary Ballot, March 2014 Republican Primary.

REPUBLICAN PARTY PARTIDO REPUBLICANO

PRIMARY ELECTION OFFICIAL BALLOT ELECCIÓN PRIMARIA BOLETA OFICIAL

HARDIN COUNTY, TEXAS CONDADO DE HARDIN, TEXAS

March 04, 2014 - 04 de Marzo de 2014

Please use a black or blue ink pen only.

Completely fill in the box provided to the left of

your choice. Make no stray marks on the

ballot. Do not use inks that soak through the

paper.

Texto de Instrucción:

Por favor use solamente una pluma de tinta

negra o azul. Llene completamente el espacio

cuadrado a la izquierda de su selección. No

Lieutenant Governor

Precinct Precinto 1

haga marcas extraviadas. No use tintas que se

pueden penetrar el papel.

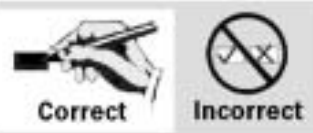

Gobernador Teniente

$\square$ Jerry Patterson

Judge, Court of Criminal Appeals, Place

Juez, Corte de Apelaciones Criminales,

$\square$ Todd Staples

Lugar Núm. 3

$\square$ Dan Patrick

$\square$ David Dewhurst

$\square$ Bert Richardson

$\square$ Barbara Walther

Attorney Genera

Procurador General

$\square$ Ken Paxton

Barry Smitherman

$\square$ Dan Branch

Comptroller of Public Accounts

"I am a Republican and I understand that I am ineligible to vote or participate in

another political party's primary election or convention during this voting year."

"Yo soy Republicano y comprendo que no estoy elegible para votar o participar en la

elección primaria o la convención de

algún otro partido político durante este año electoral."

Contralor de Cuentas Públicas

$\square$ Glenn Hegar

$\square$ Harvey Hilderbran

$\square$ Raul Torres

$\square$ Debra Medina

Judge, Court of Criminal Appeals, Place 4

Juez, Corte de Apelaciones Criminales,

Lugar Núm. 4

United States Senator

Commissioner of the General Land Office

Comisionado de la Oficina General de

Tierras

Senador de los Estados Unidos

$\square$ George P. Bush

$\square$ David Watts

$\square$ Kevin Patrick Yeary

Richard Dean Davis

$\square$ Jani Jo Wood

Judge, Court of Criminal Appeals, Place

Juez, Corte de Apelaciones Criminales,

Lugar Núm. 9

$\square$ David Newell

$\square$ W.C. "Bud" Kirkendall

Member, State Board of Education,

District 7

Miembro de la Junta Estatal de Educación

Pública, Distrito Núm. 7

$\square$ Chris Mapp

+0
$\frac{6}{0}$
0

$\square$ Dwayne Stovall

Commissioner of Agriculture

Comisionado de Agricultura

Tommy Merritt

$\square$ Eric Opiela

$\square$ Sid Miller

J Allen Carnes

$\square$ Joe Cotten

$\square$ Rita Ashley

$\square$ David Bradley

State Senator, District 3

Senador Estatal, Distrito Núm. 3

$\square$ Robert Nichols

State Representative, District 19

Representante Estatal, Distrito Núm. 19

$\square$ James E. White

Chief Justice, 9th Court of Appeals

District

Juez Presidente, Corte de Apelaciones,

Distrito Núm. $g$

United States Representative, District 36 Representante de los Estados Unidos,

Distrito Núm. 36

$\square$ Brian Babin

Kim Morrell

$\square$ Phil Fitzgerald

John Amdur

$\square$ Doug Centilli

Railroad Commissioner

Comisionado de Ferrocarriles

Malachi Boyuls

Becky Berger

Wayne Christian

$\square$ Ryan Sitton

Chief Justice, Supreme Court

Juez Presidente, Corte Suprema

$\square$ Nathan Hecht

$\square$ Robert Talton

$\square$ Steve McKeithen

Justice, 9th Court of Appeals District,

Place 3 - Unexpired Term

Juez, Corte de Apelaciones, Distrito Núm.

9. Lugar Núm. 3 - Duración Restante del Cargo

$\square$ Leanne Johnson

$\square$ Earl B. Stovar III

$\square$ Chuck Meyer

$\square$ John Manlove

Jim Engstrand

$\square$ Pat Kasprzak

Ben Streusand

Justice, Supreme Court, Place 6 -

Unexpired Term

Juez, Corte Suprema, Lugar Núm. 6 -

Duración Restante del Cargo

$\square$ Jeff Brown

$\square$ Joe Pool

Governor

Gobernador

Justice, Supreme Court, Place 7

Juez, Corte Suprema, Lugar Núm. 7

$\square$ Jeff Boyd

Justice, Supreme Court, Place 8

Juez, Corte Suprema, Lugar Núm. 8

County Judge

Juez del Condado

$\square$ David Bellow

Wayne McDaniel

District Clerk

Secretario del Distrito

$\square$ Pam Hartt

$\square$ D'Wayne Crowell

Dana Hogg

$\square$ Lora Keefer

County Clerk

Secretario del Condado

$\square$ Sharon McCally

$\square$ Phil Johnson

$\square$ Jerry Jordan

$\square$ Glenda Alston 
Figure 2. Results Portfolio for the March 1, 2016 Republican Primary for Position 5 on the Texas Supreme Court, between Paul Green and Rick Green.

(a) Histogram of Vote Shares across Counties

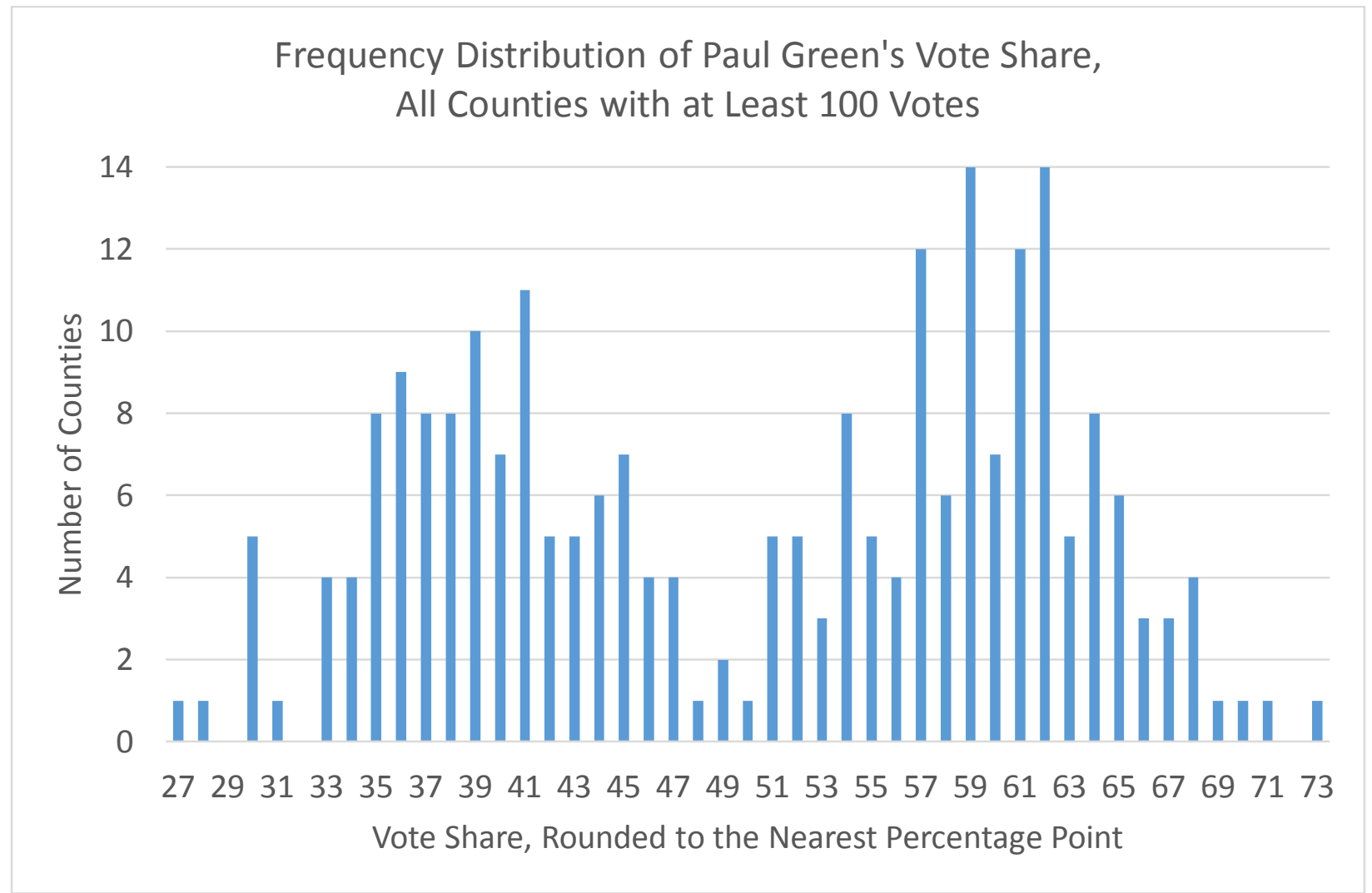

(b) Randomization Tests.

Paul Green is listed first on 121 of 233 ballots, or $51.9 \%$.

Rick Green is listed first on 112 of 233 ballots, or $48.1 \%$.

The $\chi^{2}$ test of the null hypothesis of equal proportions yields a test statistic of 0.35 , which fails to reject with a $p$-value of 0.56 . The likelihood ratio test of the null hypothesis that Paul Green's being listed first is unrelated to the independent variables described in the text yields a $\chi^{2}$ statistic of 14.14 with 16 degrees of freedom, which fails to reject with a p-value of 0.59 .

(c) Regression Results.

With control variables, the coefficient estimate on FIRST in equation (1) of the text is 19.44 with a standard error of 0.73 ; the $R^{2}$ value is 0.78 . Without controls, the coefficient estimate is 19.15 with a standard error of 0.73 ; the $R^{2}$ value is 0.75 . 